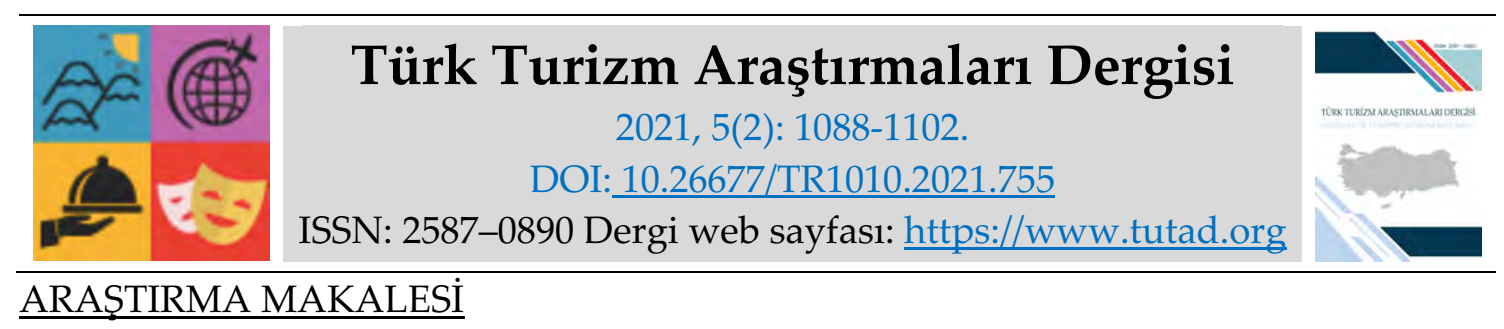

\title{
Termal Turizm İşletmelerinde Sağlık Beklentileri ve Müşteri Memnuniyeti: Bolu Örneği
}

Dr. Öğr. Üyesi Hakkı ÇILGINOĞLU, Kastamonu Üniversitesi, Turizm Fakültesi, Kastamonu, eposta: hcilginoğlu@kastamonu.edu.tr ORCID: https://orcid.org/0000-0002-6787-3397

Sercan AYTUĞAR, Yüksek Lisans Öğrencisi, Kastamonu Üniversitesi, Sosyal Bilimler Enstitüsü, Kastamonu, e-posta: aytugar16@gmail.com

ORCID: https://orcid.org/0000-0003-2506-1363

Öz

Günümüzde işletmelerin sunduğu ürün ve hizmetlerin kalitesinin sonucunda müşteri memnuniyeti oluşmaktadır. Müşteri memnuniyetini sağlayan işletmelerin, müşterilerin sadakatini kazanmakta ve pazardaki rekabete uyum sağlayabilmektedir. Çalışmanın amacı, Bolu ilindeki termal turizm işletmelerine gelen müşterilerinin beklenti ve memnuniyetlerini ölçmektir. Elde edilen verilerin incelenmesi sonucunda müşterilerin algıladıkları memnuniyetlerinin belirlenmesi ve bu doğrultuda termal turizm işletmeleri eksikliklerini belirleyerek bir çözüm olanağ1 sunacağ1 düşünülmektedir. Çalışmada nicel yöntemlerden anket tekniğine başvurulmuştur. Elde edilen veriler SPSS 22 ile analiz edilmişidir. Önem derecesi ortalaması yüksek bulunurken, memnuniyet derecesi ortalaması ise belirtilen önem derecesinin altında kaldığ 1 belirlenmiştir. Sonuç olarak jeotermal potansiyeli yüksek olan Bolu ilinin termal turizm tesislerinin müşteri memnuniyeti ortalaması orta düzeyde memnunum şeklinde olduğu belirlenmiştir.

Anahtar Kelimeler: Termal Turizm, Sağlık Turizmi, Müşteri Memnuniyeti, Müşteri Beklentileri. Makale Gönderme Tarihi: 16.04 .2021

Makale Kabul Tarihi: 05.06.2021

\section{Önerilen Atıf:}

Çılgınoğlu, H. ve Aytuğar, S. (2021). Termal Turizm İşletmelerinde Sağlık Beklentileri ve Müşteri Memnuniyeti: Bolu Örneği, Türk Turizm Araştırmaları Dergisi, 5(2): 1088-1102.

(c) 2021 Türk Turizm Araştırmaları Dergisi. 


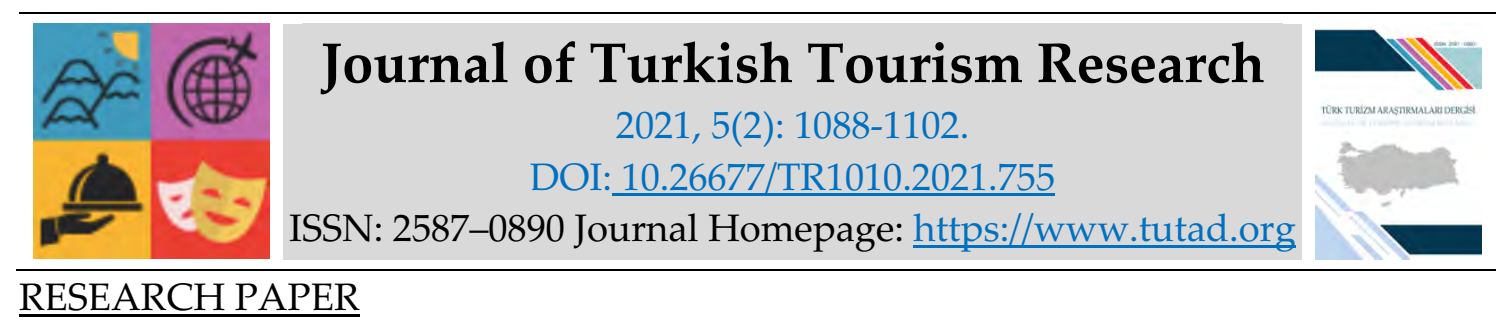

\title{
Health Expectations and Customer Satisfaction Bolu Example in Thermal Tourism Enterprises
}

Assistant Prof. Dr. Hakkı ÇILGINOĞLU, Kastamonu University, Faculty of Tourism, Kastamonu, e-mail: hcilginoğlu@kastamonu.edu.tr ORCID: https://orcid.org/0000-0002-6787-3397

Sercan AYTUĞAR, MSc. Student, Kastamonu University, Social Sciences Institute, Kastamonu, e-mail: aytugar16@gmail.com

ORCID: https://orcid.org/0000-0003-2506-1363

\begin{abstract}
As a result of the quality of products and services offered by enterprises today, customer satisfaction is formed. Businesses that ensure customer satisfaction can win customer loyalty and adapt to competition in the market. The aim of the study is to measure the expectations and satisfaction of customers who come to thermal tourism enterprises in Bolu province. As a result of examining the data obtained, it is believed that the customers will determine their perceived satisfaction and provide a solution by identifying the shortcomings of thermal tourism enterprises in this direction. In the study, quantitative methods were applied to survey techniques. The data obtained were analyzed with SPSS 22. The average degree of importance was found to be high, while the average degree of satisfaction remained below the specified degree of importance. As a result, it was determined that the average customer satisfaction of the thermal tourism facilities of Bolu province, which has high geothermal potential, is moderately satisfied.
\end{abstract}

Keywords: Thermal Tourism, Health Tourism, Customer Satisfaction, Customer Expectations. Received: 16.04 .2021

Accepted: 05.06.2021

\section{Suggested Citation:}

Çılgınoğlu, H. and Aytuğar, S. (2021). Health Expectations and Customer Satisfaction Bolu Example in Thermal Tourism Enterprises, Journal of Turkish Tourism Research, 5(2): 1088-1102.

(C) 2021 Türk Turizm Araştırmaları Dergisi. 


\section{Gíriş}

Geçmiş çağlardan itibaren insanlar, birçok sebepten dolayı yaşadığı bölgeyi terk ederek seyahat etmek zorunda kalmışlardır. Kişileri seyahat etmeye zorlayan etmenler arasında savaş, göç, ticaret, iklim, yiyecek ve içecek kaynakları ile sağlık problemleri yer almaktadır. İnsanlar sağlıklarını düzeltmek veya koruyabilmek için doktorların, şifahanelerin (hastane) veya termal kaynakların bulunduğu bölgelere seyahat ederek iyileşmeyi veya sağlıklarını korumayı amaçlamışlardır (Zengin ve Eker, 2016:166).

Rekabet ortamının gün geçtikçe artmasıyla, turizm işletmelerinin turistlerin satın alma tercihleri konusundaki istekleri üzerinde çalışmaları önem kazanmıştır. Günümüzde konaklamalı turizm, gelen turistlerin satın alma tercihleri doğrultusunda değişiklik göstermektedir (Türkmen ve Dönmez, 2015). Buna paralel olarak turistleri ağırlayan turizm işletmeleri de sürekli arayış içindedir (Dönmez ve Türkmen, 2018). Günümüzde termal suların; yenilenen tıbbı bilgiler ve gelişen teknolojinin sağlık alanlarında kullanımı sonucu gün geçtikçe modernleşen termal tesisler termal tesisler hizmete girmektedir. Özellikle, termal kaynaklar açısından zengin olan ülkemizde, termal işletmelerin fazlalığı ve gün geçtikçe sayılarının artması ile sektörde oluşan rekabet seviyesinde artış gözlemlenmekte ve bu rekabetin sonucunda ise müşteri memnuniyeti önemli bir unsur haline gelmektedir. Turizm işletmelerinin, müşterilerinin istek ve şikâyetleri dikkate alınarak müşterilerin, aldıkları hizmet süresi boyunca ürün veya hizmetin kalitesinin arttıılması, müşteri memnuniyetini ve dolayısıyla müşteri sadakatini yükseltebilmektedir. Bunun sonucunda ise işletmeler varlığını sürdürebilmekte ve ticari faaliyetlerine devam edebilmektedir (Aymankul vd., 2012:225).

Türkiye' de birçok turizm kaynağı potansiyelinin kullanılması ve bu doğrultuda turizmi 12 aya dağıtabilmesi, kıyı turizmi ile sınırlandırılmaması adına çalışmalar yürütülmektedir. Mevcut termal kaynakların yılın 12 ayına yayılabilmesi, bu konuda termal turizmin önemini arttırmaktadır. Termal turizm işletmeleri müşterilerinin, istek, şikâyet ve beklentilerinin belirlenmesi, karşılanması ve giderilmesi adına çalışmalar yapılması, müşterileri memnuniyetini sağlayarak, müşterilerin işletmeye olan bağlılıklarını arttıracak ve dolayısıyla işletmenin gelir seviyesi yükselecektir. Gerek ülke ekonomisi gerekse yurt içi ve yurt dışı turizm sektörü canlı tutularak birçok alanda gelişim ve istihdam sağlanacaktır (Gündüz, 2015:1). Türkiye sahip olduğu doğal ve kültürel değerleriyle turizm açısından gelişmiş olan ülkelerden çok daha fazla kaynaklara sahip olmasına rağmen, yerel halkın bu anlamda desteğini sağlayamadığı için turizmden elde edebileceğinden çok daha az bir gelir elde edebilmektedir (Türkmen ve Dönmez, 2015).

Bolu, Kuzey Anadolu fay hattı üzerinde yer alan, zengin jeotermal kaynaklara sahip bir şehirdir. Bölge, Turizm Bakanlığ 1 tarafından "Termal Turizm Merkezi" olarak belirlenmiş ve 17.10.1993 tarih ve 2137 sayılı Resmi Gazetede yayımlanmıştır (www.kulturportali.gov.tr). Bolu ili Türkiye genelinde en zengin termal kaynaklara sahip olan illerimiz arasında olduğu bilinmektedir. Dolayısıyla Bolu ilinin termal kaynaklarının ve termal turizm tesislerinin varlığı açısından büyük bir potansiyele sahip olduğu belirtilmektedir. Zengin termal kaynakların varlığının olmasına rağmen var olan termal turizm potansiyelini gerektiği kadar kullanamadığı, fayda sağlayamadığı, tanıtımına önem verilmediği ve olması gereken ekonomik düzeye ulaşamadığına inanılmaktadır (Bilgili, 2013).

Bolu ilinin termal kaynakları ve termal turizm işletmelerinin yönünden potansiyelinin değerlendirilmesi adına ve var olan termal tesisleri ziyaret eden müşterilerin memnuniyet ve beklenti seviyelerinin ne denli olduğunu ve ne kadarını karşıladığının belirlenmesi ve bu seviyeleri oluşturan koşulların bilinmesi önem arz etmektedir (Dereli, 2019:52-53). Verilen bilgiler doğrultusunda, araştırmada Bolu ilindeki termal turizm işletmelerine gelen müşterilerin 
memnuniyet ve beklenti seviyelerinin ölçülmesi amaçlanmıştır. Bu doğrultuda bölgenin var olan termal kaynaklarının ve termal tesislerinin gelişimi ve pazardaki rekabet ortamına ayak uydurabilmesi ve müşteri bağlılığını elde edebilmesi adına önem arz ettiğine inanılmaktadır. Çalışmanın benzer alanlarda ve yerel tesislerin gelişimi adına değer taşıdığı düşünülmektedir. Çalışma kapsamında bu gelişim için önerilerde bulunulmuştur.

\section{Sağlık Turizmi}

Dünya Sağlık Örgütü (World Health Organization [WHO])'ne göre sağlık tanımı; “Sağlık sadece hastalık ve sakatlığın olmayışı değil, bedence, ruhça ve sosyal yönden tam iyilik halidir. Bu tanımda bedence ve ruhça iyilik hali sağlığın bilinen yönüdür". Yapılan tanım ile sağlığını korumaya ve sürdürülebilirliğini sağlamak isteyen ve sağlık problemleri yaşayan kişiler sağlık turizminin hedef kitlesini oluşturmaktadır (Gülen ve Demirci, 2012).

Bulunduğumuz yüzyıl turizm olgusu, turistlerin temel ihtiyaçları, güvenlik, konaklama, yiyecek ve içecekler gibi gereksinimlerine ek olarak sağlık problemlerine çözüm aramak ve bu alanda beklentiler oluşturmaktadır. Seyahatleri sırasında veya daha önceden meydana gelmiş sağlık ihtiyaçlarını karşılamadığı ve bu doğrultuda gerçekleştirdikleri eylemler sonucu, sağlık turizmi kavramı meydana gelmiştir (Kök, 2013:5).

Sağlık hizmetlerinin uygulama faaliyetleri antik zamanlardaki uygarlıklara uzanmakta, eski medeniyetlerin birçoğu, kaynak sularından ve bu sular ile yaptıkları kutsal olarak kabul ettikleri banyolardan yararlandığı ve bu sıcak su kaynaklarının etrafına birçok yapı inşa ettikleri bilinmektedir (Türkiye Sağlık Vakfı, 2010; Dalkıran, 2017:163). Antik Yunan mitolojisinde Asklepios sağlığın tanrısını onurlandırmak adına inşa ettikleri Asklepios Tapınakları bilinen ilk sağlık merkezi konumunda hizmet vermiş ve çeşitli ülkelerden hastalıklarına şifa arayan kişilerce ziyaret edilmiştir. Ayrıca günümüzden 5000 yıl önce Hindistan'da alternatif tıp yöntemleri kullanılmış ve ülkeye sağlık sorunları olan kişilerin ziyareti gerçekleşmiştir (Gülen ve Demirci, 2012).

Ülkelerdeki sanayileşme, çarpık kentleşme ve artan nüfusun sonucu meydana gelen hava kalitesinin düşmesi, iklim değişiklikleri, çeşitli çevre sorunları, bireylerin kent ve iş hayatının getirdiği yorgunluk ve stres gibi olumsuz koşullara ek olarak dünya genelinde meydana gelen krizlerin getirdiği etkiler ile kişiler ruhsal ve fiziksel sağlıklarını koruyamamaktadır. Bu konuda kişiler turizm seyahatlerinin kitle turizmi haricinde doğası, çevresi bozulmamış iklimi ve fiziksel özellikleri sağlığına olumlu yönde etki edecek veya hastalıklarına çözüm olabilecek turistik bölgelere eğilim göstermektedirler (Türksoy ve Türksoy, 2010:700).

Sağlık turizmi kapsamında yeni bir eğilim ise, hastaların yalnızca özel bir tedavi beklemediği, ek olarak keyifli deneyimler kazanmayı ve sağlıklarını uzun bir süre korumayı amaçladıkları gözlemlenmektedir. Bu tanım ile birlikte alanında uzman kişilerin hastalara önerdiği tedavi yöntemlerinin değeri artmaktadır. Sağlık turizmi, ülkemizin ekonomik kalkınmasına destek olabilmesi için doğal kaynak bakımında zenginliğinin kullanımı önem taşımaktadır. Diğer ülkelerin paralel büyümesi, farklı çözümler ile gerçekleştirirken, doğal kaynak rezervleri ile sağlık turizmi kapsamındaki ürünlerinin geliştirilmesini sağlamış ve küresel pazarda bir bölünmeye neden olmuştur (Connell, 2006; Çılgınoğlu, 2018:184 ).

Sağlık turizmi birçok çeşitli nedenler ile uygulanmakta olduğu bilinmektedir. Buna göre; sağlık turizmi ana unsurlarl; bireylerin yaşadığı ülkede gelişmiş teknolojileri kullanan sağlık kurumlarının ve nitelikli insan kaynaklarının yetersizliği ve olmayışı, sağlık hizmetlerini alırken aynı zamanda tatil yapabilme isteği, kendi ülkelerinde sağlık hizmetleri maliyetinin yüksek olması, nitelikli ve güvenilir sağlık hizmetinden yararlanma isteği, ülkesinde çeşitli nedenler ile 
yapılacak olan ameliyat veya tedavinin öğrenilmesini istememesi, ülkesinin iklimi ve coğrafyasının tatil yapabilme imkânları açısından kısıtlı olması durumda gerçekleşen turizm hareketliliğidir. Genellikle termal tesislerin ve termal turizm olanaklarının olduğu ülkelere gerçekleşen tatil talepleri, kronik hastalığı olan kişiler, yaşlılar ve engellilerin bulundukları ortamı değiştirme ve tedavi olma isteğinin oluşması, madde bağımlıkları olan kişilerce farklı ve daha nitelikli yerlerde bulunma isteği, kişilerin yaşama bağlama ve yaşama arzusu olarak sayılabilir (Sağlık Bakanlığı, 2012:65; Özer ve Sonğur, 2012:71).

Türkiye; sağlık turizmi bünyesinde bulundurduğu nitelikli sağlık kuruluşları, gelişmiş altyapısı ve alanında uzman doktorlarıyla dünya sağlık turizmi alanında büyük bir öneme sahiptir. Her geçen gün gelişen sağlık turizminin ekonomik getirilerin arttırılabilmesi için şu anki potansiyelinin belirlenmesi ve buna doğrultuda çalışmaların hızlandırılması gerekli görülmektedir. Bu anlamda Türkiye; Avrupa ve Asya kıtalıları arasında bulunması ve çoğu ülkeye yakın olması gibi coğrafi konumunun özelliği, sağlık hizmetlerinin diğer ülkelere oranla uygunluğu, turizm kapsamında birçok aktivite ve turizm türünü barındırması ile bir avantaj sağlayarak, hastaların destinasyon tercihinde bulunabileceği bir ülke olmaktadır. Bu özelliklerin değerlendirilmesi, geliştirilmesi ve tanıtılması halinde Türkiye'nin sağlık turizm kapsamında öneminin artacağı ve değer kazanacağı düşünülmektedir (Çılgınoğlu, 2020:116-117).

\section{Termal Turizm}

Termal Turizm; sağlığını muhafaza etme veya iyileştirme amacı ile kişilerin bulundukları yerleri belirli bir süreyle terk ederek doğal kaynakların kullanımı için termal tesislere ziyareti ve termal kaynaklara dayalı, Kür hizmetleri, rekreasyon, barınma, yiyecek ve içecek gibi temel ihtiyaçlarının karşılanmasına ek olarak turistik ziyaretin yapıldığ bölgenin, doğal kaynakları, iklimi, tarihi ve kültürel varlıklarından yararlanma olanağı sunan ayrıca yöreye ait ürünlerin tadımı, bölgesel aktiviteler ve alışveriş gibi faaliyetlerden yararlanma imkanı sunan ve turistin yeni deneyimler kazanmasına olanak sağlayan bir turizm türüdür (Çelik, 2009:36). Termal turizm, literatürde kaplıca(ılıca) turizmi olarak da adlandırılmaktadır. Termal suların, yeryüzüne ulaştığ 1 yere kaynarca, bu kaynarcalardan faydalanmak için çevresine yapılan tesisler kaplıca veya ilıca olarak adlandırılmaktadır (Avderen, 2011:44).

Termal turizm, yalnızca termal sular ile günlük banyo yapılması değildir. Termal turizminin amacı; termal sular ile tıbbı olarak belirlenen endikasyon(şifa) özelliğinin alanında uzman doktorların gözetiminde etkin ve uygun tedavi yöntemlerinin uygulanmasına ek olarak; istirahat etme, rekreasyon ve fiziksel uygulamalar ile kişinin sağlığını korunması, dinç kalması ve yenilenmesi amacıyla sağlıklı yaşamı için bir ortam oluşturmaktır. Bu tanımlama ile termal kaynakların kullanıldığı termal tesisler, bir hastane, klinik veya hamam değildir. Termal turizmin temel unsurları, doğal kaynaklar, iklim, hava kalitesi ve güneşli gün sayısıyla beraber termal suların özelliklerinin uygun ve etkili uygulanmasıyla insan sağlığı ve turizmi birleştirmektir (Erdoğan ve Aklanoğlu, 2008:84).

Termal turizm uygulamaları basit ve kar oranı yüksek bir turizm türü olarak bilinmektedir. Bu durum göz önünde bulundurulduğunda termal kaynaklara sahip ülkelerin termal turizm potansiyelini belirlemeye ve doğal kaynaklarının gelişim amacıyla çalışmalar yapılmasına yöneltmektedir. Dünya, termal turizm alanında gelişime yönelik çalışmaları yaparken, Avrupa kıtası bu alanda avantajlı konumdadır. Avrupa kıtasında ortalama 1500 termal tesise sahiptir ve her geçen gün gelişimine devam etmektedir. Geçmişte kişiler hastalıklarına çözüm aramak için sağlık kurumlarına müracaat ederken günümüzde hastalar ve kişiler dinlenme, sağlıklarını koruma, iyileştirme ve yenileme amacıyla termal turizme katıldığı gözlemlenmektedir. Termal turizm kapsamındaki işletmelerin önemlerinin arttığını gözlemleyen ülkeler termal 
kaynaklarının tanıtımına, termal turizm kapsamındaki hizmetlerin gelişimine ve markalaşması adına önemli çalışmalar yapmaktadır (Tokmak, 2015; Dereli, 2019:41).

Türkiye, zengin jeotermal kaynak potansiyeli ile dünya genelinde ilk yedi ülke arasında yer alırken, Avrupa kıtasında birinci sırada bulunmaktadır. Türkiye mevcut termal suları, debi ve sıcaklık özelliklerine ek olarak fiziksel ve kimyasal özelliklerinin çeşitliliği ile Avrupa kıtasındaki termal sulara göre daha yüksek niteliklere sahiptir. Türkiye, "doğal çıkışlı ve bol su verimli, eriyik maden değeri yüksek, kükürt, radon ve tuz" yönünden verimli ve zengin termal kaynaklara sahiptir. Bu yönüyle, çeşitli sağlık sorunlarına yönelik alternatif termal kaynaklara sahipliğinden bahsedilebilir. Türkiye' de mevcut $1500^{\prime}$ ün üzerinde olan termal kaynak suları, sıcaklıkları $20^{\circ} \mathrm{C}$ ve üzerinde debileri 2-500 lt/sn aralığında değişiklik göstermektedir (Erdoğan ve Aklanoğlu, 2008:85).

Termal Turizm; Termal mineralli sular ile yapılan banyolar, mineralli su kürleri, inhalasyon uygulamaları ve çamur banyoları gibi birçok yöntem ile klimaterapi, rehabilitasyon ve fizik tedavi gibi destek uygulamaların birleşmesiyle gerçekleştirilen kür (tedavi) uygulamalarına ek olarak termal suların rekreasyon amacı ile kullanımı sonucu oluşan bir turizm türüdür (yigm.ktb.gov.tr).

\section{Termal İşletmelerde Müşteri Kavramı}

Müşteri kavramı, günümüz işletmelerinin hedef noktası olarak belirlediği ve önemi her geçen gün artan bir unsur haline gelmeye başlamıştır. Pazarlamacılar, müşteri daima önceliklidir, ifadesini benimsemişlerdir (Jackson, 2001:856). İşletmeler için mevcut pazarın rekabet alanına dâhil olabilmeleri veya rakip işletmelerin gerisinde olmamaları hatta diğer firmaların önüne geçebilmesi, hedef pazarı iyi analiz edebilmesi, anlaşılması ve işletme müşterilerini bir ticari varlık olarak benimsemesinden çok, müşteriyi bir dost olarak nitelendirmesi ile mümkün olabilmektedir (Sandıkçı, 2008:51).

Geçmişte sağlık işletmesine giden bir müşteri sadece hastalar olarak nitelendirilirken, günümüz sağlık işletmelerine giden ve işletmenin hizmetinden yararlanan kişiler ve kurumlar müşteri olarak tanımlanmaktadır (Kavuncubaşı, 2000). Sağlık işletme personeli ve işletme ile organik bir bağı olan kişiler ya da gruplar iç müşteri kavramını oluştururken, Sağlık işletmesinin verdiği ürün ya da hizmetlerden doğrudan ya da dolaylı yoldan kullanım sağlayan kişi veya kurumlar sağlık işletmesi dış müşteri kavramını oluşturmaktadır (Çelik, 2009:198).

\section{Müşteri Memnuniyeti ve Beklentileri}

Müşteri memnuniyeti; İşletmenin sunduğu ürün veya hizmetleri kullanan müşterilerin ürün veya hizmetin kalitesi, sunumu, gibi özelliklerinin değerlendirerek müşteride oluşan olumlu veya olumsuz düşünceleri kapsamaktadır (Altan ve Engin, 2003:85).

Müşteri memnuniyeti ya da başka bir ifade ile müşteri tatmini, kuşkusuz işletmelerin dikkat ettiği stratejiler içinde en değerli unsurlardan biridir. 1980 yllından itibaren, birçok ülke işletmelerin üzerinden durduğu ana konulardan biridir. İşletmelerin varlığının, karlılı̆̆ını, pazar paylarındaki büyüme yüzdeleriyle doğrudan ilişkili olan müşteri memnuniyeti, başlıca işletmelerin sadakatine(loyalty) bağlıdır (Eroğlu, 2005:9). Müşterilerin yararlanacağı hizmetten umduğu kalite ile hizmetin uygulanmasından sonra ulaştığ gerçek kalite arasında elde edilen fark, memnun olma ölçüsünü gösterir. Müşteri memnuniyetini oluşturan etmenleri tanımlarken, ürün performans ve kalite beklentisine ek olarak müşteriyle oluşturulan bağ, müşteriye olan ilgi ve tavırlar görmezden gelinmemelidir (Kırım, 1997:157). 
Beklenti, ilk izlenime benzer bir şekilde zahmetsizce meydana gelmekte ve bu etki ise epey bir süre boyunca devam edebilmektedir. Bu sebeple beklenti oluşumunu sağlayan unsurlar ve beklentileri zamanla etkileyen değişkenlerin belirlenmesi firmalar adına önemli bir rol teşkil etmektedir. Kişisel beklentiler ve algılanan ürün veya hizmetlerin arasındaki ayrımlar ne denli azaltılırsa, müşterilerin memnuniyet düzeyleri de o denli artış göstermektir. Genel yargılar beklentileri oluşturmakta ve bu beklentilerin sağlanması ise tahminle neticelendirilmektedir (Sandıkçı, 2008:61).

Termal işletmeleri, sağlik ve birçok hizmet imkânlarından faydalanmak için tesise gelen müşteriler, tesislerde verilen hizmetler için bazı beklentiler oluşturmaktadır. Termal tesislerde verilen hizmetlerden yararlanan her müşteri için algı düzeyi farklılık göstermektedir. Termal tesislerin yöneticileri, verilen hizmetin müşterilerin beklenti ve görüşlerini belirlemesi ve anlaması, verilen hizmetin kalitesinin arttırılmasına ve müşterilerin beklentilerini karşılaması için büyük bir önem arz etmektedir. Ayrıca personelin müşterilere daha iyi hizmet verebilmesi adına, tesis çalışanlarının müşterilerin beklenti ve görüşlerini doğru anlaması gerekmektedir (Giritlioğlu, 2013:331-332).

Termal turizm işletmeleri yönünden müşteri memnuniyetinin oluşturulması ve devamlılığının sağlanmasının değeri net bir şekilde görülmektedir. Müşteri memnuniyeti turizm sektörünün bünyesinde bulunan konaklama işletmeleri yönünden değerlendirilmesi gereken ana konular içerisinde yer almaktadır. Başka sektörlerde genellikle müşteriler belirli bir ücret ile aldıkları ürünleri, ürünün kullanım süresi boyunca kullanarak yararlanmaktır. Turizm işletmelerinde ise, kişilerin beklentileri; zihinsel ve fiziksel olarak yenilenme, dinlenme, sağlıklarını koruma, yenileme ve geri kazanma gibi unsurlardan meydana gelmektedir. Bu hizmetlerin sonucunda ise kişilerin elde ettikleri yeni deneyimler, aktiviteler ve sağlıklı aktivitelere katılım olacaktır (Sandıkçı, 2008:79).

Termal turizm işletmelerinde misafir memnuniyeti, sadece konaklama, yeme içme ve rekreasyon hizmetlerinin kusursuz verilmesiyle sağlanamamakta, ayrıca misafirlerin öncelikli geliş amaçları olan sağlık beklentilerinin ne derece karşılandığıyla da alakalı olmaktadır. Bu doğrultuda Bolu'da bulunan termal tesislere katılım sağlayan müşterilerin, beklenti ve memnuniyetlerinin belirlenmesi ile müşteri sadakatini sağlanabilmesi ve tesisin varlığını devam edebilmesi adına önem teşkil etmektedir.

\section{YÖNTEM}

Araştırma konusunun amacı, sağlık turizmi içerisinde olan termal turizm işlemelerine katılan müşterilerin, beklenti ve memnuniyet seviyelerinin ölçülmesi ve elde edilen sonuçlar ile Bolu ilinde bulunan termal tesislerin iyileştirilmesi ve müşteri sadakatini yakalayarak bölgeye istihdam sağlaması ve katkıda bulunabilmesidir.

Araştırmada Sandıkçı́nın (2008) yılında doktora tezinde kullandığı anket ölçeği kullanılmıştır. Araştırma evrenini Bolu ilinde bulunan termal tesis müşterileri oluşturmaktadır. Bunun başlıca nedeni geçerli ve güvenilir yanıtlara erişebilmesi adına tesisleri ziyaret etmiş ve tesis hakkında bilgi sahibi olmuş kişilere ulaşmaktır. Bolu'nun evren olarak tercih edilme nedeni ise termal kaynaklara ve tesislere sahip olmasıdır. Ocak 2021-Mart 2021 tarihleri arasında 50 kişiye anket uygulanmış ve 33 kişinin anketi uygun bulunmuştur. Araştırma kapsamında birincil verilere başvurulmuştur. Araştırmanın işleyebilmesi adına gerekli bulunan nitelikli verileri çeşitli yöntemler kullanılarak kişinin bireysel olarak elde ettiği veriler birinci veriler olarak tanımlanmaktadır. Birincil verilerin toplanabilmesi adına anket tekniğine başvurulmuştur. 
Anket, katılımcıların belirlenen sıralama ve yapılardaki soruları cevaplaması ile elde edilen nicel araştırma yöntemlerinden bir tekniktir (Altunışık vd., 2002:71).

Çoğunlukla yapılan çalışmalarda başvurulan, nicel yöntemlerden anket tekniğinin güvenilirliğinin ölçülmesi amacıyla Cronbach's Alpha güvenilirlik testi yapılmaktadır. Testin katsayısı 0 ve 1 arasında olan sayılardır. Sayı, 1'e ne denli yakınsa güvenilirliğinin de o denli yüksek olduğu bilinmektedir (Özdamar, 2004:633). Çalışmada kapsamındaki ankete uygulanan Cronbah's Alpha değeri 0,920 olarak hesaplanmıştır. Elde edilen değerin güvenilir olduğu saptanmıştır.

Tablo 1. Anket Güvenirlik Test Sonucu

\begin{tabular}{lll}
\hline Cronbach's Alpha & $\begin{array}{l}\text { Cronbach's Alpha Based on } \\
\text { Standardized Items }\end{array}$ & N of Items \\
\hline 920 &, 935 & 23 \\
\hline
\end{tabular}

\section{BULGULAR}

Çalışma kapsamında Ankete katılan sayısı 50'dir ve değerlendirmeye alınacak sayı ise 33 kişi olarak belirlenmiştir. Ankette öncelikle katılım gösteren kişilere ait demografik bilgileri ölçmek adına sorular bulunmaktadır. Elde edilen sonuçlar aşağıdaki Tablo 2.'de verilmiştir.

Tablo 2. Katılımcıların Demografik Dağılımları

\begin{tabular}{llcc}
\hline & & $\mathrm{N}$ & $\%$ \\
\hline \multirow{3}{*}{ Cinsiyet } & Kadın & 19 & 57,6 \\
& Erkek & 14 & 42,4 \\
& Toplam & 33 & 100 \\
\hline \multirow{4}{*}{ Yaş } & $16-25$ & 3 & 9,1 \\
& $26-33$ & 7 & 21,2 \\
& $36-45$ & 9 & 27,3 \\
& $46-55$ & 8 & 24,2 \\
Eğitim Durumu & 55 ve üstü & 6 & 18,2 \\
& Toplam & 33 & 100 \\
\hline \multirow{5}{*}{ Gelir Seviyesi } & İköğretim & 5 & 15,2 \\
& Lise & 12 & 36,4 \\
& Önlisans & 6 & 18,2 \\
& Lisans & 9 & 27,3 \\
& Doktora & 1 & 3,0 \\
& Toplam & 33 & 100 \\
\hline \multirow{5}{*}{} & 1500 TL'den az & 3 & 9,1 \\
& $1500-3000$ & 13 & 39,4 \\
& 3000-5000 & 11 & 33,3 \\
& 5000-7500 & 2 & 6,1 \\
& 7500 TL ve üstü & 4 & 12,1 \\
& Toplam & 33 & 100 \\
\hline
\end{tabular}

Katılım gösteren kişilerin \% 57,6 erkektir. Yaş aralığının belirlenmesinde $\% 27,3$ oranla en yüksek değer 36-45 yaş aralığıdır. Ankete katılan kişilerin öğrenim düzeyleri değerlendirildiğinde $\% 36,4$ 
oranla en yüksek değer lise mezunu olarak belirlenmiştir. Katılımclların aylık gelirleri belirlenmeye çalışıldığında en yüksek \%39,4 oranla "1500-3000 arası" aylık ücret aldıkları saptanmiştır.

Verilen demografik bilgilere ek olarak anket dâhilindeki kişilere işletmeyi tercih etme sebepleri ve işletmeye geliş amaçları hakkında sorular iletilmiştir. Elde edilen bilgiler tablo 3 'te incelenmiştir.

Katılımclardan elde edilen veriler doğrultusunda oluşturulan tablo 2 incelendiğinde tesisin tercih edilmesinde en büyük etken \%63,6 oranla "arkadaş ve akraba tavsiyesi" olarak belirlenmiştir. Dolayısıyla müşterilerin beklentilerinin karşılanması ve işletmeden memnun ayrılmaları sonucunda algıladıkları memnuniyeti, çevresinde bulunan kişilere aktararak, tesisin tanınırlığı sağlanmaktadır. Ayrıca \%9,1 oranla seyahat acentelerinin fazla bir etkisi olmadığı belirlenmiştir. Tesislerin mevcut yerel seyahat acenteleriyle iletişiminin artması ve bu eksikliğin giderilmesi adına ortak çalışmalarda bulunulması gerektiği düşünülmektedir.

Katılımcıların tesise geliş amaçlarının belirlenmesinde \% 51,5 "Dinlenme" ve \%39,4 oranla "Tedavi" amaçlarıyla tesise geldiklerini saptamıştır. Tedavi ve dinlenme en çok tercih edilen seçenek olmuştur. Bunun sonucunda tesise gelenlerin iş ve yaşam alanlarında yaşadıkları stresi azaltmak, sağlıklarını korumak ve iyileştirmek amaçları ile tesisi ziyaret ettiğini söyleyebiliriz.

Tablo 3. Tesis Tercih Etmenleri ve Geliş Amacı

\begin{tabular}{llcc}
\hline & & $\mathrm{N}$ & $\%$ \\
\hline & Kendi Tecrübelerim & 6 & 18,2 \\
& Arkadaş, Akraba Tavsiyesi & 21 & 63,6 \\
Tesis Tercihinin Oluşumu & 3 & 9,1 \\
& Seyahat Acentesinin Tavsiyesi & 2 & 6,1 \\
& Yazılı Medya (Dergi, Gazete) & 1 & 3,0 \\
& Diğer & 33 & 100 \\
\hline & Toplam & 13 & 39,4 \\
& Tedavi & 17 & 51,5 \\
Tesise Geliş Amacı & Dinlenme & 1 & 3,0 \\
& İşs & 1 & 3,0 \\
& Merak & 1 & 3,0 \\
& Diğer & 33 & 100 \\
\hline
\end{tabular}

Tablo 4'de katılımcıların aldığ çalışılmıştır. Buna göre; ön büro hizmetlerinde, en fazla önem verilen değişken 'karşılama ve bilgilendirme" olduğu gözlemlenmiştir. Sonrasında "ilgi ve nezaket" önemli olarak değerlendirilmiştir. "Personelin tecrübesi" en düşük değeri almıştır.

Örneklemde bulunan müşteriler en önemli olarak ifade ettikleri "karşılama ve bilgilendirme" konusunda orta derece memnun kaldıklarını lakin çok memnunun ve memnunum seviyesinin altında kaldıklarını belirlenmiştir. Diğer iki değişkenin verileri rakamsal olarak ortalama aynı değeri taşıdığından bu yorum iki değişken içinde bahsedilebilir.

Ön büro hizmetlerinin, özellikle misafirlerin karşılanmasının önemi belirlenmiştir. Buna göre tesis çalışanlarının misafirlere göstermiş oldukları tutum, ilgi ve alaka sonucu misafirlerin memnuniyet seviyeleri belirlenmektedir. Tablo 3'te elde edilen veriler ile göz önüne alındığında 
otelin, müşteri sadakatini yakalamasında ve müşterilerin, çevresinde bulunan kişilere tesisi önerebilmesi adına büyük bir önem taşımaktadır.

Oda hizmetleri önemlilik düzeyine ilişkin elde edilen verilerde katılımcılar tarafından "mefruşatın kalitesi" değişkenler arasında en önemli konu olarak belirlenmiştir. İkinci önem verilen değişken "odanın konforu" seçilirken en önemsiz değişken ise "oda temizliği" olmuştur.

Müşteriler tarafında en önem verilen "mefruşatın kalitesi" algılanan memnuniyet puanlarına göre geride kalarak orta derece memnun olarak belirtilmiştir. Diğer iki değişken arasında ortalama benzer farklar belirtilmiştir. Verilen memnuniyet seviyeleri orta düzeyde memnunum ifadesi ile belirtilen önem düzeylerinin altında kalmıştır.

Oda hizmetleri, belirlenen önem derecesinin altında kalmıştır. Dolayısıyla müşteri sadakatinin yakalanması ve tesisin varlığının devam edebilmesi adına memnuniyet düzeyinin arttırılması gerektiğine inanılmaktadır.

Yiyecek ve içecek hizmetlerine ilişkin yantlarda müşterilerin puanlarına göre en fazla önem "personelin ilgi ve nezaketi" olarak gösterilmiştir. En düşük önem seviyesinde ise "Diyet yiyecek ve içecek yeterliliği" olmuştur. Ortalama verilen önem dereceleri "önemli" şeklindedir. Algılanan memnuniyet derecesi ise "orta derecede memnunum" şeklindedir. En düşük memnuniyete sahip olan "diyet yiyecek ve içecekleri yeterliliği" olmuştur.

Yiyecek ve içecek hizmetleri genel olarak belirlenen beklentinin, ortalama bir puan altında kalmıştır. Sağlığının korunması ve iyileştirilesi adına tesise gelen misafirlerin yağsız, tuzsuz ve haşlama yöntemiyle pişirilmiş sebze gibi yiyeceklere yönelimi olağandır. Özellikle alınan tedavi sonrası vücut için sindirimi kolay besinlerin tüketilmesi gerekli görülebilir. Bu nedenle tesiste sunulan diyet yiyecek ve içeceklerin düzenlenmesi ve beklenilen memnuniyet seviyesine ulaşması büyük bir önem taşımaktadır.

Tablo 4. Hizmetlerin Önem ve Memnuniyet Değerleri

\begin{tabular}{|c|c|c|c|c|c|c|}
\hline \multirow[b]{2}{*}{ Ön büro Hizmetleri } & \multicolumn{3}{|c|}{ Önemlilik Düzeyi } & \multicolumn{3}{|c|}{ Memnuniyet } \\
\hline & $\mathbf{n}$ & $x$ & $\mathbf{s}$ & $\mathbf{n}$ & $\mathbf{x}$ & $\mathbf{s}$ \\
\hline Karşılama ve Bilgilendirme & 33 & 4,5758 & 90244 & 33 & 3,9697 & ,88335 \\
\hline $\begin{array}{l}\text { Konaklama Esnasinda İlgi ve } \\
\text { Nezaket }\end{array}$ & 33 & 4,5455 & 90453 & 33 & 3,8788 & ,92728 \\
\hline Personelin Tecrübesi & 33 & 4,4242 & 1,03169 & 33 & 3,8182 & ,95048 \\
\hline Oda ve Kat Hizmetleri & & & & & & \\
\hline Odanin Konforu & 33 & 4,7576 &, 50189 & 33 & 3,9394 & ,89928 \\
\hline Mefruşatın Kalitesi & 33 & 4,8182 & 46466 & 33 & 3,6061 & 1,14399 \\
\hline Odanın Temizliği & 33 & 4,6061 & 82687 & 33 & 3,4242 & 1,22552 \\
\hline Yiyecek ve İçecek Hizmetleri & & & & & & \\
\hline Ünitelerin Temizliği & 33 & 4,4848 & 83371 & 33 & 3,6364 & ,82228 \\
\hline Yiyecek ve İçecek Çeşit ve Yeterliliği & 33 & 4,5155 & 87039 & 33 & 3,4242 & 1,03169 \\
\hline Diyet Yiyecek ve İçecek Yeterliliği & 33 & 4,1515 & 1,30195 & 33 & 2,8485 & 1,25303 \\
\hline Personelin Tecrübesi & 33 & 4,5758 & 90244 & 33 & 3,5455 & 1,27698 \\
\hline Personelin İlgi ve Nezaketi & 33 & 4,6970 & 68396 & 33 & 3,8181 & 1,18466 \\
\hline
\end{tabular}

Önem derecesi: 5 Çok önemli, 4 Önemli, 3 Orta derece önemli, 2 Az önemli, 1 Önemsiz.

Memnuniyet derecesi: 5 Çok memnunum, 4 memnunum, 3 Orta derece memnunum, $2 \mathrm{Az}$ memnunum, 1 Memnun değilim. 


\section{SONUÇ ve ÖNERILLER}

Müşteri memnuniyeti kapsamında işletmelerin imajlarının değerini belirlemeyi hedefleyen istatistikî verilere göre; işletmeden memnun olmayan bir müşteri algıladığı memnuniyetsizliği 10 kişiye aktarmaktadır. Bu kişilerin \%13'ü ise yaşadığı sorunları ortalama 20 kişiye aktarmaktadır. Bu aktarım sonucu ise oluşan olumsuz düşüncelerin onarımı zorlaşmakta ve reklam kanalları ile düzeltilememektedir. İşletme hizmet ve ürünlerinde memnun kalan kişiler ise bu memnuniyetlerini ortalama 3 ila 5 kişiye aktarmaktadır. Buna göre memnun olmayan her müşteriye karşı 3 ila 4 müşterinin memnun bırakılması gereklidir (Gerson, 1997:21). Turizm kapsamında müşteri memnuniyeti, dikkate alınması gereken hassas bir konudur. Müşteri beklentilerinin karşılanması ve memnuniyet sağlanması müşterilerin destinasyon tercihini etkileyecek ve çevrelerinde bulunan akraba ve(ya) arkadaşlarına önerebilmesine etkili olacaktır (Silvestri vd., 2017). Yapılan bu öneriler ile turizm sektörünün gelişimi ve sürülebilirliği sağlanmış olacaktır (Canan, 2018:231). Bu açılama sonucunda işletmelerin imajlarının korunması ve işletmenin varoluş amacına uyabilmesi adına müşterilerin problemlerinin giderilmesi ve isteklerinin değerlendirilmesi ile müşteri sadakatinin kazanılması, işletmenin varlığını sürdürebilmesine ve büyüyebilmesi için yarar sağlayacaktır. Tüketici memnuniyetini sağlamak için ve isteklerinin değerlendirilmesi ile müşteri sadakatinin kazanılması, işletmenin varlı̆̆ını sürdürebilmesine ve büyüyebilmesi için yarar sağlayacaktır.

Anketin ön büro hizmetlerinin ortalaması $(4,51)$ ile "çok önemli" olarak belirlenmiştir. Üç değişken arasında en önemli bulunan "karşımla ve bilgilendirme" $(4,57)$ olmuştur. Bu değişkeni sırasıyla "konaklama esnasında ilgi ve nezaket" $(4,54)$, "personelin tecrübesi" $(4,42)$ takip etmiştir. Müşterilerin, ön büro hizmetleri memnuniyet ortalaması ise $(3,88)$ olmuştur. Beklenen önem düzeyini yakalayamadığı görülmektedir. Lakin memnuniyet derecesi "orta düzeyde memnunum" şeklinde belirlenmesi ile hizmetlerden ortalama memnun oldukları görülmektedir. Anket sonuçlarına göre en çok önem verilen "karşılama ve bilgilendirme", memnuniyet sonuçlarında $(\% 42,4)$ ile en çok memnun kalınan değişen olmuştur. Bunun sonucunda beklentileri karşıladığı görülmektedir.

Ön büro hizmetleri, tesis genelinde önemli bir rol üstlenmektedir. Misafirlerin karşılaştığ 1 ilk bölüm olmaktadır. Tesiste bulunan diğer bölümlere göre misafirlerin dilek ve şikâyetleriyle daha fazla ilgilenmesi gerekmektedir (Kunakitkumjorn, 2003; Sriyam, 2010:7). Misafirlerin, tesiste konakladığı süre boyunca tüm olumsuz etkilerden uzak tutulmasının yanı sıra personel tarafından misafire, olumlu etkiler bırakabilmek adına samimi, ilgili ve çözüm odaklı yaklaşımlarda bulunulması gerekmektedir (Mankame, 2021). Dolayısıyla müşterilerin, beklentileri ve memnuniyet düzeylerinin karşılanması adına ön büro çalışanlarının performanslarını koruyabilmesi, pratik çözümler üretebilmesi ve müşterilere karşı ilgi ve nezaketini kaybetmemsi adına çalışmalarda bulunulmalıdır (Patah vd., 2009).

Oda ve kat hizmetlerinin ortalama $(4,72)$ ile "çok önemli" olarak ön büro hizmetlerine göre daha çok önemli olduğu belirlenmiştir. Değişkenler arasında en önemli bulunan "mefruşatın kalitesi" $(4,81)$ olmuştur. Geriye kalan iki değişken önemi derecesi sırasıyla "Oda konforu" $(4,75)$, "odanın temizliği" $(4,60)$ olmuştur. Ön büro hizmetlerinde olduğu gibi memnuniyet derecesi ortalaması $(3,65)$ ile belirlenen önem derecesinin altında kalmıştır. Elde edilen verilere göre beklenilen memnuniyet derecesini karşılamadığ 1 ve "orta derece memnunum" olarak değerlendirildiği anlaşılmıştır. En düşük önem derecesine sahip olan "odanın konforu" ise verilere göre $(3,93)$ en çok memnun kalınan değişken olmuştur.

Çoğu tesis, odanın konumu ve temizliğini önemli bir ölçüt olarak görmektedir. Misafirlerin, oda seçiminde çeşitli tercihlere yönelimi görülmektedir. Dolayısıyla kişisel beklentiler çeşitlilik göstermekte ve misafirlerin, memnuniyetlerinin karşılanması adına tesis çalışanları zaman 
zaman güçlük çekmektedir (Pachero, 2017). Bu nedenle misafirlerin beklentilerinin karşılanması ve verilen hizmetin en üst düzeyde tutulması büyük bir önem taşımaktadır. Hizmet standartlarının ve kalitesinin korunabilmesi ve geliştirilmesi adına oda temizliğinin, ekipman kalitesinin ve kontrolünün düzenli olarak yapılması gerekmekte ve personele bu konular hakkında temel bilgiler ve eğitimler verilmelidir. Ancak Soulidou ve arkadaşlarının (2018) yılında yapmış oldukları araştırmada oda ve kat hizmetlerinin otel seçimlerinde büyük bir rol oynamadığını ama gerekli standartlarda bulunmayan odaların, müşteri memnuniyetinde olumsuz sonuçlar doğurduğunu ve diğer hizmetlerle bu açığı kapatmanın misafirleri tatmin etmediğini ve hayal kırıklığına uğrattığını belirlemiştir (Pizam, 1994; Valachis vd., 2009; Soulidou vd., 2018). Sonuç olarak oda ve kat hizmetlerinin kalitesinin misafirlerin memnuniyet seviyelerini etkilediği belirlenmiştir.

Yiyecek ve içecek hizmetlerinin ortalaması ise $(4,48)$ ile "çok önemli" şeklinde değerlendirilmiştir. Değişkenler arasında en çok önem verilen ise "personelin ilgi ve nezaketi" $(4,69)$ olmuştur. Sonrasında önem verilen değişkenler sırasıyla "personelin tecrübesi" $(4,57)$, "yiyecek ve içecek çeşitleri" $(4,51)$, "ünitelerin temizliği" $(4,48)$, "diyet yiyecek ve içecek çeşitliliği" $(4,15)$ olarak belirlenmiştir. Diyet yiyeceklere verilen önem derecesi düşük bulunmuştur. Lakin sağlık işletmesi ve misafirlerin yaşları itibariyle bu değişkenin önem derecesinin yüksek olması gerektiği düşünülmektedir. Müşterilerin algıladıkları memnuniyet $(3,45)$ ile "orta derecede memnunum" olarak belirtilen önem düzeyinin altında kaldığı saptanmıştır. Diğer belirtilen hizmetler gibi belirtilen önem derecesine ulaşamadığı belirlenmiş, ancak ortalama bir memnuniyet düzeyi olduğu anlaşılmıştır.

Tesisin yiyecek ve içecek bölümünde çalışan personelin, misafirlerin memnuniyetinin belirlenmesinde önemli bir etken olduğu görülmektedir (Alhelalat vd., 2017). Yiyecek ve içeceklerin servisi, personelin tecrübesi, misafire olan tutum ve davranışlar gibi etmenler misafirlerin memnuniyetinin oluşumunda olumlu sonuçlar oluşturabileceği gibi olumsuz sonuçlarda meydana getirebilmektedir (Rimmington ve Yüksel, 1998). Ek olarak personelin, kişisel temizliğine önem vermesi ve üniformasının görünümü dâhil birçok unsur misafirlerin, memnuniyetini olumlu yönde etkilemekte ve iyi bir izlenim bırakmaktadır (Lee ve Choi, 2020). Yiyecek ve içecek bölümü çalışanlarının, misafir memnuniyetini arttırabilmesi adına öncelikle personelin, iyi hizmet sunabilmesi için çalışma şartları, sosyal hakları ve çalışma saatleri üzerine olumlu düzenlemeler yapılıdır (Emir vd., 2018). Dolayısıyla personel, memnuniyetinin elde edilmesi ile motive olan çalışanların, hizmet kalitesinin artacağına inanılmaktadır.

Sağlık turizmi kapsamında yapılan termal turizm müşterilerinin, sağlıklarını korumak ve iyileştirmek amacıyla tesise geldiği göz arda edilmemelidir. Katılımcılar tarafından tesiste bulunan diyet yemeklerinin yetersizliği hakkında gerekli düzenlemelerin yapılması büyük bir önem teşkil etmektedir. Klosse'un (2019) yaptığı çalışmasında yemeklerin lezzetli hale getirilmesi ve işlenmiş gıdalardan kaçınılması gerektiğini savunmakta ayrıca taze besinlerden hazırlanan yiyeceklerin lezzetini koruyabildiğine inanmaktadır. Bu düşünce aynı zamanda taze besinlerden üretilen yiyeceklerin, misafirlerin sağlını korumasına da yardımcı olacağına inanılmaktadır. Sonuç olarak diyet menülerin oluşturulması, sağlık kapsamında seyahat eden misafirlere, tatil süreleri boyunca amaçlarına ulaşmasında yardımcı olacağına inanılmaktadır.

Dünya nüfusunun yaşlanması ile birlikte kişilerin sağlıklarını koruma ve iyileştirme amaçları sonucunda termal turizme olan talepler artmıştır. Termal işletmelerinin yatırımlarına önem verilmesi, müşterilerin beklentilerinin karşılanması ve müşterilerin memnun edilmesi sonucunda işletmeler müşteri sadakatini kazanabilmektedir. 
Müşteri sadakatinin kazanılması ile tesislerin, yoğun rekabet ortamına sahip turizm pazarında önemli avantajlara sahip olacağına inanılmaktadır (Coutinho Pires dosSantos vd., 2016:63; Tuncer vd., 2020:1378). Bolu ili ve Türkiye'de bulunan termal tesislerin güçlü ve zayıf yönlerinin saptanması, yapılan öneri ve şikâyetlerin değerlendirilmesi ile literatüre ve özel sektöre önemli katkılar sağlanabileceği düşünülmektedir.

\section{KAYNAKÇA}

Alhelalat, J. A., Ma'moun, A. H. and Twaissi, N. M. (2017). The impact of personal and functional aspects of restaurant employee service behaviour on customer satisfaction. International Journal of Hospitality Management, 66: 46-53.

Altan, M. ve Engin, O. (2003). Bir Seyahat İşletmesinde Müşteri Memnuniyetinin Ölçülmesi, Sosyal Ekonomik Araştırmalar Dergisi, 3(6): 84-98.

Altunışık, R., Coşkun, R., Yıldırım, E. ve Bayraktaroğlu, S. (2002). Sosyal Bilimlerde Araştırma Yöntemleri: SPSS Uygulamalı. Sakarya: Sakarya Kitabevi.

Avderen, S. (2011). Iç̧ Anadolu Bölgesi'ndeki Kaplıca ve Termal Tesislerin Türk Sağlık Turizmi İçindeki Yeri, Yüksek Lisans Tezi, Niğde Üniversitesi, Niğde.

Aymankuy, Y., Akgül, V. ve Can Akgül, C. (2012). Termal Konaklama İşletmelerinde Müşteri Memnuniyetine Etki Eden Unsurlar "Gönen Kaplıcaları Örneği", Balıkesir Üniversitesi Sosyal Bilimler Enstitüsü Dergisi, 15(28): 223-240.

Connell, J. (2006). Medical Tourism: Sea, Sun, Sand and Surgery. Tourism Management, 27(6): 10931100.

Coutinho Pires dos Santos, B., Filomena Torres, M., Cunha, C. and Duran Sanchez, A. (2016). Thermal resorts of Extremadura and engagement with consumer in Facebook (Spain), Enlightening Tourism. A Pathmaking Journal, 6(1): 63-85.

Çelik, A. (2009). Sağlık Turizmi Kapsamında Termal İşletmelerde Sağlık Hizmetleri Pazarlaması ve Algllanan Hizmet Kalitesi: Balçova Termal İşletmesinde Bir Uygulama, Yüksek Lisans Tezi, Dokuz Eylül Üniversitesi, İzmir.

Çılgınoğlu, H. (2018). Sağlık Turizminin Temel Özellikleri, Eğilimleri ve Pazarın Küreselleşmesi Üzerine bir Değerlendirme. Electronic Turkish Studies, 13(22): 179-192.

Çılgınoğlu, H. (2018). Uluslararası Sağllk Turizminin Ekonomik, Hukuki ve İdari Yönden Değerlendirilmesi: Türkiye'deki Hastaneler Üzerinde Örnekleme, Doktora Tezi, Kastamonu Üniversitesi, Kastamonu.

Dalkıran, G. B. (2017). Bir Sağlık Turizmi Destinasyonu Olarak Trakya Bölgesi, Sosyal Bilimler Araştırma Dergisi, 6(4): 162-178.

Dereli, N. (2019). Bolu'nun Termal Turizm Potansiyeli ve Termal Turist Profili, Yüksek Lisans Tezi, Eskişehir Osmangazi Üniversitesi, Eskişehir.

Dönmez, Y. and Türkmen, F. (2015). Turistlerin Satın Alma Kararında Peyzaj Düzenlemelerinin Rolü: Belek Örneği. Turizm Akademik Dergisi, 2(2): 16-27.

Dönmez, Y. and Türkmen, F. (2018). The relation between the landscape design and brand image in purchase preferences of tourists: The case of Safranbolu and Nevşehir, in Turkey. Applied Ecology and Environmental Research, 16(1): 629-643. 
Emir, O., Şahin, S. and Arslantürk, Y. (2018). An Assessment of The Impact of Employee Satisfaction on Customer Satisfaction in Hotel Enterprises. İşletme Araştırmaları Dergisi, 4: 794-806.

Erdoğan, E. ve Aklanoğlu, F. (2008). Termal Turizm ve Afyon-Gazlıgöl Örneği, E-Journal of New World Sciences Academy, Natural and Applied Siences, 3(1): 83-92.

Eroğlu, E. (2005). Müşteri Memnuniyeti Ölçüm Modeli, İ.Ü. İşletme Fakültesi Isşletme Dergisi, 34(1): 7-25.

Gerson, R. F. (1997). Müşteri Tatmininde Süreklilik, (Çeviren, Savaşer, T.) İstanbul: Rota Yayınları.

Giritlioğlu, İ. (2013). Yiyecek İçecek Bölümlerinde İşgörenlerin ve Müşterilerin Hizmet Kalitesi Beklenti ve Algıları: Termal Otellerde Bir Araştırma, Balıkesir Üniversitesi Sosyal Bilimler Enstitüsü Dergisi, 16(29): 329-355.

Gülen, K. G. ve Demirci, S. (2012). Türkiye'de Sağllk Turizmi Sektörü, İTO Yayınları, Yayın No: 201139. İstanbul.

Gündüz, H. (2015). Sağlık Turizmi Kapsamında Pamukkale Termal Kaynaklarının Değerlendirilmesi ve Sağglık Bakanlığı Belgeli Otellerde Müşteri Memnuniyetinin Belirlenmesi, Yüksek Lisans Tezi, İzmir Kâtip Çelebi Üniversitesi, İzmir.

https://www.kulturportali.gov.tr/turkiye/bolu/TurizmAktiviteleri/bolu-kaplicalari> [Erişim Tarihi, 05.01.2021].

https://yigm.ktb.gov.tr/TR-11475/genel-tanimlar.html> [Erişim Tarihi, 10.12.2020].

Jackson, J. (2001). Prioritising Customers and other Stakoholders Using the AHP, Europen Journal of Marketing, 35(7-8): 858-871.

Kavuncubaşı, Ş. (2000). Hastane ve Sağllk Kurumları Yönetimi. Ankara: Siyasal Kitapevi.

Keskin, Y. (2008). Termal Turizm İşletmelerinde Müşteri Tatmininin Ölçülmesi Kızılcahamam Örneği, Yüksek Lisans Tezi, Düzce Üniversitesi, Düzce.

Kırım, A. (1997). Yeni Dünyada Strateji ve Yönetim. İstanbul: Der Yayınları.

Klosse, P. R. (2019). The taste of a healthy and sustainable diet: What is the recipe for the future?. Research in Hospitality Management, 9(1): 35-42.

Kök, M. (2013). Sağlık Turizmi Açısından Termal Turizm (Denizli Örneği), Yüksek Lisans Tezi, Beykent Üniversitesi, İstanbul.

Lee, B. and Choi, J. (2020). Effect of staff appearance on customer satisfaction and revisit intention. International Journal of Services, Economics and Management, 11(2): 119-136.

Mankame, M. S. (2021). Study on Hotel Front Office Practices and Its Impact on Guest Satisfaction. Palarch's Journal of Archaeology of Egypt/Egyptology, 18(1): 4545-4550.

Müşteri Memnuniyeti Uzmanlık Grubu, (2000). Müşteri Memnuniyeti Yönetimi. İstanbul: Kalder Yayınları.

Özdamar, K. (2004). Paket Programlar ile İstatistiksel Veri Analizi. Eskişehir: Kaan Kitabevi.

Özer, Ö. ve Sonğur, C. (2012). Türkiye'nin Dünya Sağlık Turizmindeki Yeri ve Ekonomik Boyutu, Mehmet Akif Ersoy Üniversitesi Sosyal Bilimler Enstitüsü Dergisi, 4(7): 69-81.

Pacheco, L. (2017). Customer satisfaction in Portuguese hotels: Evidence for different regions and hotel segments. Tourism Analysis, 22(3): 337-347. 
Patah, M. O., Radzi, S. M., Abdullah, R., Adzmy, A., Zain, R. A. and Derani, N. (2009). The Influence of Psychological Empowerment on Overall Job Satisfaction of Front Office Receptionists. International Journal of Biometrics, 4(11): 167-176.

Pizam, A. (1994). Planning a Tourism Research Investigation, (Editör) J.R.B. Ritchie and C. R. Goeldner.: Tourism and Hospitality Research, A Handbook for Managers and Researchers (91-103) New York: John Wiley \& Sons.

Rimmington, M. and Yüksel, A. (1998). Tourist satisfaction and food service experience: Results and implications of an empirical investigation. Anatolia: Turizm Araştırmaları Dergisi, 9(1): 37-57.

Sağlık Bakanlığı (2012). Să̆glk Turizmi El Kitabı. Ankara: BMS Matbaacılık.

Sandıkçı, M. (2008). Termal Turizm İşletmelerinde Sağlık Beklentileri ve Müşteri Memnuniyeti, Doktora Tezi, Afyon Kocatepe Üniversitesi, Afyonkarahisar.

Silvestri, C., Auilani, B. and Ruggieri, A. (2017). Service quality and customer satisfaction in thermal tourism. The TQM Journal, 29(1): 55-81.

Soulidou, A. K., Karavasilis, G. I., Vrana, V. G., Kehris, E. C., Theocharidis, A. I. T. and Azaria, A. H. (2018). Factors affecting hotel selection: Greek customers' perception. TOURMAN 2018 Conference Proceedings, 28 October 2018, pp. 90-97, Rhodes, Greece.

Sriyam, A. (2010). Customer satisfaction towards service quality of front office staff at the hotel. Master degree, Srinakharinwirot University, Bangkok.

Tokmak, C. (2015). Termal Turizm. Ankara: Detay Yayıncllı.

Tuncer, O., Menekay, M. and Savaşan, A. (2020). Perspectives of Customers Staying in Thermal Tourism Operations for Thermal Tourism Satisfactions. International Journal of Early Childhood Special Education (Int-Jecse), 29(5): 1370-1381.

Türkiye Sağlık Vakfı (2010). Dünyada ve Türkiye'de Sağlık Turizmi 2010 Durum Analiz Raporu ve Çözüm Önerileri. Ankara: Efil Yayınevi.

Türkmen, F. \& Dönmez, Y. (2015). Korunan alanların turizme açılmasına ilişkin yerel halkın görüşleri (Yenice örneği). Karabük Üniversitesi Sosyal Bilimler Enstitüsü Dergisi, 5(2): 189-204.

Türksoy, A. ve Türksoy, S. S. (2010). Termal Turizmin Geliştirilmesi Kapsamında Çeşme İlçesi Termal Kaynaklarının Değerlendirilmesi, Ege Academic Review, 10(2): 699-725.

Valachis, I., Christou, E., Sigala, M. and Maroudas, L. (2009). Developing Human Resources' skills and Knowledge in Tourism and Hospitality Industry Through the Determination of Quality of Training Programs. Tourism and Hospitality Management, 15(1): 61-72.

Varol-güneş, F. K. and Canan, F. (2018). Determination of Customer Requirements for Thermal Accommodation Facility Designs. Afyon Kocatepe Üniversitesi Sosyal Bilimler Dergisi, 20(2): 231248.

Zengin, B. ve Eker, N. (2016). Sakarya İli Termal Turizm Potansiyelinin Değerlendirilmesi, Kastamonu Üniversitesi İktisadi ve İdari Bilimler Fakültesi Dergisi, 13(3): 165-181. 